The Third Pole: Journal of Geography

Vol. 20 - 21: 71-82, 2021

DOI: https://doi.org/10.3126/ttp.v21i01.41619

Department of Geography Education,

Central Department of Education, T.U., Kathmandu, Nepal

\title{
RURAL LIVELIHOODS AT RISK: A CASE OF DEVGHAT GAUNPALIKA IN THE WESTERN HILLS, NEPAL
}

\begin{abstract}
Shiba Prasad Rijal ${ }^{1}$
Abstract

People's livelihood determines by a variety offactors-availability of assets, opportunities, and restrictions created by the environment, and people's evaluation of these factors. The present paper aims to analyze adversities of rural livelihoods focusing on the case of Devghat Gaunpalika of Tanahun district, Nepal. This article is based on primary data/ information acquired from a field survey conducted during December 2017 through group discussion, key informant interview, and field observation. People in the Devghat area perform farm and off-farm activities to eke out wide shorts of their livelihood needs. However, livelihood in this area is at risk owing to combination of adversities such as food insufficiency, shortage of facilities and services, low level of educational attainment, lower household income, and others. Three-fourth of the households adopted agriculture as ther main occupation to fulfil their household needs. Household income is low. Aboutof 62 percent households earn below NRs 5000 per month. Twenty-five percent of the population earns their livelihood by working as wage-based labors. A low level of educational attainment and poor coping capacity also indicate local livelihoods at risk.
\end{abstract}

Keywords: Adversities, assets, institutional environment, livelihood, risk, seasonality, wellbeing.

\section{Introduction}

Livelihoods in rural Nepal are at risk, and people make their livelihoods in the adverse situations created by the factors of the local environment, trends, shocks, and seasonality. These factors affect people's livelihood by influencing the availability of assets and options to pursue beneficial livelihood outcomes (Wyss, 2004). The components of trends

1 Dr. Rizal is a Professor, Department of Geography Education, Tribhuvan University, Kathmandu, Email: rijalshibaprasad@gmail.com 
and seasonality may have positive effects for better livelihoods, too; however, many of these factors are directly or indirectly the sources of hardships. People pursue livelihood strategies based on the combination of assets they own and command, and opportunities and restrictions created by the environment (Pain \& Lautze, 2002). Many choices and options are generally open to the people; the actual livelihood depends on the peoples' evaluation (Knowled \& Wareing, 1996). A rural livelihood comprises one or more often several activities, which variously provide food, cash, and other goods to satisfy a wide variety of human needs (Chambers \& Conway, 1991). The observations of Ellis (1998) is similar, he claims that the diversified strategies are less vulnerable compared to non-diversified ones. People organize to transform the environmental opportunities to meet their livelihood needs through technology, labor, power, knowledge, and social relations (Hoeck, 2001). The access to assets has probably the significance influence on the choice of livelihood strategies (Chambers \& Conway, 1991; Scoones, 1998; DFID, 1999). However, the role of socio-cultural norms and values is significant as people in the same region adapt different strategies, and the strategies of the same ethnic group may differ by region.

An enormous diversity of livelihood strategies exist (Bishop, 1990; Zoomers, 1999; Bhurtel, 2000; Dahal, 2001; Subedi \& Pandey, 2002; Sulivan et al., 2004, Rijal, 2006 $\&$ 2007) in Nepal within geographic areas, sectors, within households and over time as a result of variation in environment, socio-economic, and cultural factors. Subedi et al. (2007) claimed that the people's livelihood in the mid-western Nepal is stressful and at risk as caused by varieties of factors, including diseases outbreaks, and others. Likewise, Bohle and Adhikari (1998) have shown food insufficiency as a major risk of livelihoods. Koirala (2010) claimed that the livelihood practices depend on locational characteristics and suitability of the area. As people perform varieties of activities to secure livelihoods, agriculture is the mainstay of livelihood for the most of the households in the hills of Nepal (Khatiwada, 2010).

Rural Nepal exhibits a wide variety of environmental, physical, economic, and sociocultural adversities upon which people's livelihood depends. Studies reviewed so far showed diversities in rural livelihoods that based on opportunities and restrictions created by the environmental settings, assets owned, and choice of local people, while some of them are focused on risk factors associated with livelihoods in general. None of the studies reviewed highlights the case of Devghat Gaunpalika. Thus, the present study is an attempt on this line. 


\section{Methods and Materials}

Study Area: Devghat Gaunpalika (rural municipality) located at Tanahun district in the Gandaki province is selected as the study area. The Gaunpalika was created with the restructuring of Nepal by merging four Village Development Committees, namely Baidi, Dveghat, Chhipchhipe, and Kota, with a decision of the Government of Nepal of March 2017 under the provision of the new constitution of Nepal 2015. The Gaunpalika extends in between $27^{\circ}$ $52^{\prime} 29^{\prime \prime}$ North and $27^{\circ}$ 44' 29" North latitude and $84^{\circ} 17^{\prime} 41^{\prime \prime}$ East and 84'28'27" East longitudes (Figure 1) and covers an area of 159 sq. km. The elevation ranges from 183 to $1618 \mathrm{~m}$ from the mean sea level.

There were 3435 households with 16,131 populations (female 53.60 percent male 46.40 percent) in the

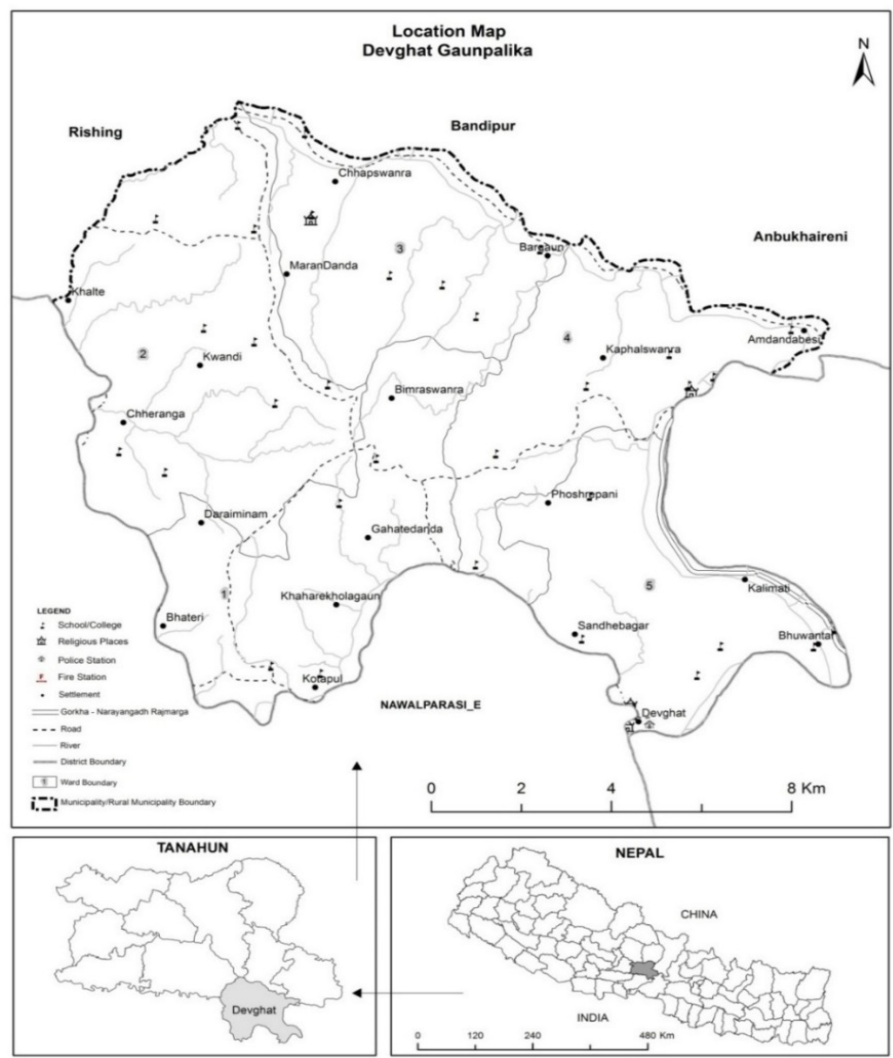

Figure 3: Location of the study area

Gaunpalika (DDC, 2073

BS). Many caste and ethnic groups inhabit the Gaunpalika. Magar, the largest ethnic group in the Gaunpalika, accounted for almost 40 percent of the total population. Gurung accounted for 28.08 percent, followed by Brahmin (7.83 percent), Gharti (5.8 percent), and the remaining others. About 70 percent of the people of 5 years and above were literate in the Gaunpalika.

Study Methods: The present study is based on primary data/information acquired through a field survey during December 2017. A field survey was conducted using different methods like group discussion, key informant interview, and field observation. Five group discussions were organized in five wards in the study area representing 
6-8 persons from different occupations. These include schoolteachers, social workers, and others. In addition, ten key informants, two from each ward, were also consulted with intensive field observation. Data/information was gathered from varieties of published and unpublished sources. The information regarding different characteristics of population and livelihood options was acquired from the Gaunpalika profile, and official records. The data/information regarding the status of food sufficiency was collected from group discussion. Likewise, statistics on available facilities and services were acquired from both group discussion and key informants' interviews. The gathered information/data are analyzed with verification through information triangulation from different sources.

\section{Results and Discussion}

Livelihood Strategies: People fulfill their livelihoods needs within a complex and diverse set of economic, social, and physical circumstances pursuing varieties of strategies based on assets they own and command within the environment of opportunities and restrictions (Pain \&Lautze, 2002). A rural livelihood comprises several activities, which variously provide food, cash, and other goods to satisfy a wide variety of human needs (Chambers \& Conway, 1991). The enormous diversity of livelihood strategies exists within geographic areas because of variation in environmental, socio-economic and cultural factors. However, the actual livelihood of the people is determined by the peoples' choice.

People of the Devghat Gaunpalika area have adopted varieties of livelihood strategies to fulfill their household needs. These include agriculture, business, services in government and non-government agencies, and physical labor. Among these, the involvement of people in agriculture, including livestock farming, is high, accounting for about 50 percent of the total economically active population. Twenty-five percent of the population earn their livelihood by working as wage-based labors, whereas 10 percent of the population of this area is involved in the service sector, in both governmental and non-governmental agencies. Around 10 percent of the population is engaged in business activities, whereas 5 percent of the total workforce is employed in foreign employment for their livelihood (Figure 2). 


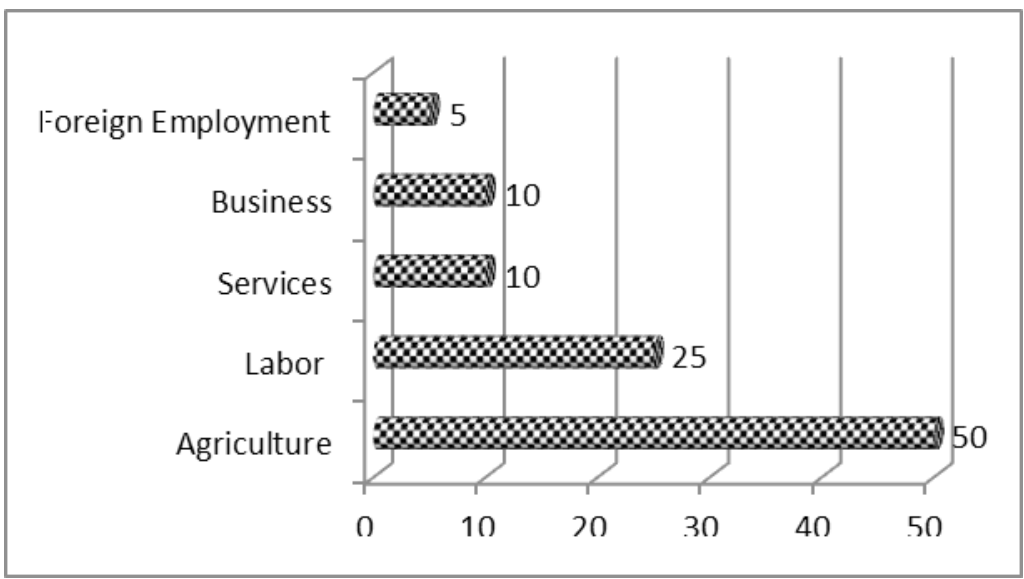

Figure 2: Percentage of the population engaged in different livelihood activities

Source: Data from Official Records of Devghat Gaunpalika, 2018

People in Devghat Gaunpalika have adopted varieties of livelihood strategies; however, they have been living at risk owing to combination of adversities. These include both natural and related to anthropogenic activities.

Adversities in Livelihoods: The livelihood of people in the Devghat Gaunpalika area is at risk owing to varieties of adversities. These adversities are directly or indirectly associated with trends, shocks, and seasonality, which may have positive effects too. However, many are the sources of hardships. The adversities in livelihood identified in the study area include food insufficiency, shortage of facilities and services, low educational attainment, lower household income, high dependence on remittance, and others. These adversities make livelihood insecure and misfortune. The following sections provide a brief account of significant adversities of people's livelihood.

Food insufficiency: About 50 percent of people in the Devghat Gaunpalika are engaged in agriculture and produce varieties of crops like cereals, pulses, fruits, and vegetables. Despite agriculture being the main occupation of the people in this area, the agriculture production in this area is low due to the traditional method of farming with insufficient irrigation facilities. As a result, three-fourth of the population does not produce sufficient foods for their household requirement (Table 1). The proportion of households making adequate food for 10 to 12 months is merely 19.6 percent. Fourteen percent of the household can manage food requirement from their production for up to three months only, whereas 30 percent of households produce food for up to six months from their 
production. About 22 percent of the population of the Gaupalika can manage food for 6-9 months from their production. Only 7 percent of households produce surplus food items to their household requirement. They sell surplus amout of their production in the local market.

Table 1: Household's food sufficiency status in Devghat Gaupalika

\begin{tabular}{|l|c|}
\hline Food sufficiency & Percent Household \\
\hline$<3$ months & 14.2 \\
\hline $3-6$ months & 29.7 \\
\hline $6-9$ months & 22.3 \\
\hline $10-12$ months & 19.6 \\
\hline Surplus production & 07.2 \\
\hline Total & 100.00 \\
\hline
\end{tabular}

Source: Field Survey, 2017

As agricultural production is insufficient to meet the household food requirements, people have adapted varieties of measures to fulfill household food requirements. Those who do not produce sufficient food items manage household food requirements through purchasing food items from the local market using the income received from remittances and wage labor. However, livestock is an important component of the farming system, and it has remained an integral part of agriculture in the Devghat Gaunpalika. The contribution of livestock is not significant as many households do not either keep or keep a very limited number of animals. The contribution of livestock to local livelihood is minimal.

Insufficient facilities and services; The provision of utilities plays a significant role in creating wealth, and makes livelihoods comfortable. Utilities such as energy, water, sanitation, and telecommunication support the economic, social, and environmental performance (CSIR, 2005). The quality of livelihood depends on reliable facilities, and services (CBS, 2014). These physical assets ensure better livelihoods through enhancing work ability of the people, and income generation, and ultimately, increase level of wellbeing.

People of the Devghat Gaunpalika area have minimal access to life-supporting facilities and services; as a result, a large portion of the residents have been living in hardship. The provision of transport facility is not good though roads connect it. There are altogether 73-kilometer roads ( $28 \mathrm{~km}$ graveled and $45 \mathrm{~km}$ earthen). However, all the roads within the Gaunpalika area are in poor condition, and most of the earthern 
roads become muddy and remain closed during rainy season and dusty during the dry season. Both movements of people and goods transportation become hard during rainy season. Likewise, the health facility is not developed well in the Gaunpalika. There are few health institutions ( 5 health posts, one clinic, and two medical shops) which provide health services to the local people, especially in minor injuries and diseases. There is no specialized treatment. Many low income-earning people are deprived of specialized health facilities, as they cannot afford specialized medical services in cities located farther apart from their residence. The sanitation situation in the Gaunpalika is quite good, however; still, a significant proportion of the people do not have access to toilet facilities. They used to defecate at open spaces, forests, and riverbanks resulted in contamination of water sources and environmental pollution. Regarding drinking water, people use varieties of water sources such as piped water, wells, and others; the supply of pure and safe water is insufficient. Still, people in many places have been using unsafe water from rivers and streams for household purposes. Thus, the possibility of the outbreak of water-borne diseases is high in these areas. Likewise, access to facilities in terms of electricity is limited. Almost 50 percent of households are out of reach of electricity. They use alternative sources of energy like kerosene and others for lighting. Except in small market areas, people use fuel wood for cooking purposes, which makes the in-house environment smoky and unhealthy.

Access to and use of financial institutions is another indicator for livelihood wellbeing. People's access to financial institutions is limited in this area. There is only a bank and few cooperatives providing financial services to the local people. Still, large portions of people obtain loans from the local moneylenders paying high interests rates. Though interest from banks and cooperatives is comparatively lower, people prefer getting loans from the village elites. This might be due to poor financial literacy of the people, and lengthy formalities, and lack of collateral for the loan from financial institutions. Likewise, access to information and communication facilities is very limited. Only six percent of the households own television, whereas the percentage of households with radio is about 22 percent. Access to computers is rare (less than 1 percent of households), and internet facility is available to less than 0.5 percent of households. This indicates that a large proportion of the population is deprived of facilities and services.

Low Educational Attainment: Devghat Gaunpalika looks good in terms of the establishments of educational institutions. There are 39 educational institutions of different levels of formal education in the Gaunpalika. In addition, there are 30 child development centers, including eight basic and primary schools in the Gaunpalika. However, a large number of five years and above population (almost 9 percent) is out of formal schooling. The level of literacy in terms of the number of people who can read 
and write is quite good (70.11 percent). Of them, nearly three-fourth of the population has an only a basic level of education (Table 2).

Table 2: Educational status of people aged five and above

\begin{tabular}{|l|c|}
\hline Description & Percent of Population \\
\hline Basic School & 74.07 \\
\hline High School & 16.10 \\
\hline Bachelor & 0.58 \\
\hline Masters & 0.35 \\
\hline Non-formal Education & 8.90 \\
\hline Total & 100.00 \\
\hline
\end{tabular}

Source: District Profile, 2017

The proportion of the population having a higher level of education (Bachelor and Master) is less than one percent, which indicates the low level of educational attainment in the Gaunpalika.

High Dependence on Remittance: Remittance is one of the primary sources of the Nepalese economy; no doubt, it is the primary source of the local economy of Devghat area as well. As reported, a total of 800 working-age people of this Gaupalika are migrated to different countries for earning opportunities. The major destinations abroad include Qatar, Malaysia, Dubai, Saudi Arabia, UAE, Korea, and Bahrain. In addition, mny people migrated to India in search of seasonal employment, especially in the agriculture and harvesting season. As a large proportion of the population is working outside the country, they send their earned income to their family members through different banking and non-banking channels. The annual income of around 0.2 million is received in 2017 in the Gaupalika from the remittance. The proportion of job holders within the country is limited as compared to migrated abroad. This indicates the high dependency of the local economy on the external sources of income. Income from remittance is used mainly for meeting household requirements like the purchase of gadgets like television, mobile phones, laptops, video players, etc., rather than capital formation. They also invest in land for housing purpose.

Low Household Income: Income level plays a vital role in maintaining the level of livelihoods, social status, and power. The story of wellbeing reflected in the provision of household amenities and services primarily determines by the level of household income. Likewise, it has direct and indirect implications on children's education as well. It helps in cushioning risk and vulnerability from natural disasters and illness. The 
choice of earning activities determines the level of income. As noted above, agriculture, services, business, foreign employment, and physical labor are the major sectors for employment; the household income of local people largely depends on these sources. The combined incomes derived from these sources in different households of the Gaunpalika are categories into five groups, and is presented in Table 3.

Table 3: Average Monthly Income of Household

\begin{tabular}{|l|c|}
\hline Income (NRs) & Household (Percent) \\
\hline Below 5,000 & 61.6 \\
\hline $5,000-10,000$ & 3.95 \\
\hline $10,000-15,000$ & 5.26 \\
\hline $15,000-25,000$ & 13.16 \\
\hline Above 25,000 & 15.85 \\
\hline
\end{tabular}

Source: Official Records, Devghat Gaunpalika, 2017

The study reveals the low level of household income of the people of the Devghat Gaunpalika area. The majority of the household (61.6 percent) earn below NRs 5000 per month. Around 16 percent of households earn above NRs 25,000 per month. Similarly, the proportion of households earning between NRs 5000 to 10,000 per month is about 4 percent. The low level of household income indicates the high level of poverty of the local people.

Environmental Risks: Nepal is one of the most disaster-prone countries in the world and faces several natural disasters every year. Unstable steep slopes and fragile geological formation of a young mountain range with heavy monsoon rainfall lead to a wide range of geological and hydro-meteorological disasters across the country (MoHA, 2013). The most frequent hazards are floods, landslides, epidemics, fires, and earthquakes, causing heavy loss of human lives, including housing and infrastructures (NSET, 2008). Being located in the fragile and unstable slopes in the Mahabharat region, the Devghat Gaunpalika area is not free from risks of different hazards like landslide, flood, seismic, and others. There is a high risk of seismicity, which has clearly been observed with the considerable movement of Main Boundary Thrust (MBT) that is extended along the east-west in the southern part of the Devghat Gaunpalika (Paudyal, 2014). Likewise, landslide is a frequent phenomenon of this area due to high tectonic activities, haphazard development activities, and fragile environment coupled with high-intensity rainfall. The haphazard road construction in the Siwalik region with a concentration of settlement and little forest coverage indicates high susceptibility to landslide hazards. 
The area is not free from fire hazards as well. Past evidences show that this area is quite susceptible to fire hazards. As reported in the District Disaster Preparedness and Response Plan (2074 BS), the Baidi and Kota areas of this Gaunpalika is highly vulnerable to fire hazards. Some of the settlements located nearby forest, those houses made-off of wood, and other combustible materials are more susceptible to fire hazards. It was also observed that in many rural settlements, houses are in clusters adjoining to each other, and some of them are used to store fuel woods, straw, and other combustible material inside or connecting to homes, a clear indication of being prone to fire hazards. This area is not free from wind storms, hot and cold waves, droughts, thunderbolts, and cloudburst. The risks associated with climatic components have been increasing with global climate change. The risk of windstorms is common in this area, especially in the pre-monsoon season. Frequent thunderbolts are common in the pre-monsoon season. The loss of crops and other properties by thunderbolts is common. This reveals that the livelihood of people residing in this area is at risk of natural hazards.

\section{Conclusions}

The livelihood of people in the western hills of Nepal is at risk and also hard due to varieties of adversities. The livelihood of poor and marginalized people is even hard. People in this area perform varieties of activities to eke out a wide variety of their livelihood needs based on the availability of assets and environmental opportunities and restrictions. Agriculture is the main occupation of the people and crop production is dominated by cereals, a large proportion of the household do not produce sufficient foodstuffs for their household requirements, as agriculture in large parts of this area depends heavily on monsoon rain and traditional practice, resulted in low production. Likewise, shortage of quality life-supporting facilities and services, poverty, and lower educational attainment reflect adverse situations, and poor cooping capacity. Mountainous topography with high susceptibility of landslides and other risks and activities without considering risks also reflects insecure livelihood. Intensification of agriculture with the development of irrigation, and other facilities, and livelihood activities based on risk assessment can help reduce adversities of local livelihood, thereby increasing the level of wellbeing.

\section{References}

Bhole, H. G., \& Adhikari, J. (1998). Rural livelihoods at risk: How Nepalese farmers cope with food insecurity. Mountain Research and Development, 18 (4): 321-332.

Bishop, B. C. (1990). Karnali under stress: livelihood strategies and seasonal rhythms in a changing Nepal Himalaya. Illinois: University of Chicago. 
Central Bureau of Statistics (CBS). (2014). Population monograph of Nepal (Volume III): Economic Demography, Kathmandu: CBS.

Chambers, R. \& Conway, G. R. (1991). Sustainable rural livelihoods: practical concepts for the $21^{\text {st }}$ century (Discussion Paper 296). Bridgton: Institute of Development Studies (IDS).

Council for Scientific and Industrial Research (CSIR) (2005). Guidelines for human settlement planning and design (Volume I), Pretoria: CSIR Building and Construction Technology.

Dahal, K. B. (2001). Struggling with development: a case study of the changing livelihood strategies of the Baramus from western Nepal. Unpublished Master's thesis in Sociology/Anthropology, Tribhuvan University.

Department for International Development (DFID). (1999). Sustainable livelihoods guidance sheets. London: DFID.

Devghat Gaupalika. (2074 BS). Gaupalika parswachitra-2074 (Rural municipality profile 2074), Devghat Gaunpalika.

District Administration Office (DAO). (2074 BS). Jilla Bipad Purbatayari Tatha Pratikarya Yojana 2074, (In Nepali), DAO, Tanahun.

District Development Committee (DDC). (2073 BS). District profile of Tanahu (In Nepali). Tanahun: DDC

Ellis, F. (1998). Livelihood diversification and sustainable rural livelihoods. In: D. Carney (Ed). Sustainable Rural Livelihoods: What contribution can we make? London: Department for International Development.

Government of Nepal (GoN). (2074 B.S). Gaupalika tatha nagarpalikako sanchhipta parichaya pustika 2074 (In Nepali). Kathmandu: GoN, Ministry of Federal Affairs and Local Development.

Hoeck, W. van der. (2001). Water and rural livelihoods. Retrieved from http://www. ifpri.org/2020/focus09/ focus09_05.htm.

Khatiwada, S. P. (2010). Continuity and change of livelihood activities in the TankhuwaKhola Watershed in Eastern Hills, Nepal. In: Pradhan, P. K. Subedi, B. P. \&. Khanal, N. R. (Eds.), Environmental, Livelihood and Micro-Enterprises. Kathmandu: Central Department of Geography, Tribhuvan University, pp 121-134.

Knowled, R. \& Wareing, J. (1996). Economic and social geography. New Delhi: Rupa \& Co.

Koirala, H. L. (2010). Changing livelihood strategies in the hills and mountains: Experiences of eastern Nepal. In: Pradhan, P. K. Subedi B. P. \&. Khanal, N. R (Eds.), Environment, Livelihood and Micro-Enterprises. Kathmandu: Central Department of Geography, Tribhuvan University, pp 47-60. 
Ministry of Home Affairs (MoHA) (2013). Nepal disaster report 2013: Focus on participation and inclusion, Kathmandu: MoHA and Disaster Preparedness Network-Nepal (DPNet-Nepal).

National Society for Earthquake Technology-Nepal (NSET). (2008). Global assessment of risk- Nepal country report (Draft final), Kathmandu: NSET

Pain, A. and Lautze, S. (2002). Addressing livelihoods in Afghanistan. Kabul:Afghanistan Research and Evaluation Unit.

Rijal, S. P. (2007). Land Holding and Livelihoods: A synthesis from Modi Khola Watershed, Nepal, The Third Pole, 5-7: 43-51.

Rijal, S. P. (2006). Livelihood strategies and income level of people of Modi watershed, Nepal. The Himalayan Review, 37: 9-37.

Scoones, I. (1998). Sustainable rural livelihoods: a framework for analysis (Working paper 72). Brigton: Institute of Development Studies.

Subedi, B. P. and Pandey, R. (2002). Livelihood strategies of Rai communities in Arun valley: Continuity and change. In Chaudhary, R. P; Subedi, B. P; Vetaas, O. R and Aase, T. H. editors, Vegetation and society: their interaction in the Himalayas. Kathmandu: Tribhuvan University, Nepal and University of Bergen, Norway, pp 157-170.

Subedi, B. P., Subedi, V. R., Dawadi, P. P., \& Pandey, R. (2007). Livelihood at risk: Findings from mid-western Nepal. Kathmandu: Informal Sector Service Center (INSEC).

Sulivan, C. A., Rijal, S. P., Shrestha, M., Khanal, N. \& O'regan, D. P. (2004). An assessment of the potential impacts of climate-induced deglaciation on communities and their livelihoods in the Hindu Kush-Himalaya. (DFID KAR Project No. R7980). Wallingford: Center for Ecology and Hydrology.

Wyss, S. (2004). Organization and finance of International labour migration in Nepal. Kathmandu: Nepal Institute of Development Studies.

Zoomers, A. (1999).Linking livelihood strategies to development: experiences from the Bolivian Andes. Amsterdam: Royal Tropical Institute. 